Maxym Ageev, Assoc. Prof., PhD tech. sci.

Kherson State Maritime Academy, Ship Power Plant Operation, c. Kherson, Ukraine

e-mail:maxageev73-73@ukr.net

Sergiy Dovzhuk, head of academic laboratory

Central Ukrainian National Technical University, Kropyvnytskyi, Ukraine

e-mail:beryuza@ukr.net

Volodymyr Nikolaychuk, assistent, Tetiana Khrypko, assistent

Vinnytsia national agrarian unsversits, c. Vinnytsia, Ukraine

e-mail:niko-v@ukr.net

\title{
The Influence of Design Parameters for Electric arc Equipment on the Factors of Spray Process and Properties of Coatings
}

The paper considers possibilities to increase the wear resistance, corrosion resistance, and service life for parts machines and mechanisms via their hardening and renovating using electric arc coatings characterized by high density, adhesion strength, and micro hardness thanks to activation of the spraying process. Also, the possibility of controlling the properties of restored surfaces owing to choice of the related equipment with required structure and characteristics in order to prolong the service life of machinery parts is shown. The right choice of equipment for spraying makes it possible to increase the speed and temperature of the spraying gas and particles, reduce the droplet diameter, increase the density and reduce the oxidation of coatings. The influence of spray factors such as the flow rate and pressure of working gases, composition of combustion mixture, spraying distance, dispersion of the spray, properties of wire material, etc. on the properties of the coatings obtained has been investigated.

electric arc spraying, spraying process, wear resistance, corrosion resistance, adhesion strength, protective coating, electric arc coating

М.С. Агеев, доц., канд. тех. наук

Херсонская морская академия, г. Херсон, Украина

С.А. Довжук, зав. лаб.

Центральноукраинский Национальный технический университет, г. Кропивницкий, Украина

В.Я. Николайчук, ассист., Т.Е. Хрипко, асист.

Винницкий национальный аграрный университет, г. Винница, Украина

\section{Влияние конструктивных параметров оборудования для электродугового} напыления на факторы процесса напыления и свойства покрытий

В работе предложено повышать износостойкость, коррозионную стойкость и срок службы деталей машин и механизмов при их упрочнении и реновации ЭДН-покрытиями с высокой плотностью, прочностью сцепления и микротвердостью за счет активации процесса напыления. В работе рассмотрена возможность за счет выбора конструктивных параметров и характеристик оборудования для ЭДН управлять свойствами восстановленных поверхностей с целью повышения ресурса деталей машин. Правильный выбор конструкции оборудования для напыления позволит увеличить скорость и температуру струи транспортирующего газа и частиц, уменьшить диаметр капель, повысить плотность и снизить окисляемость покрытий. В работе исследование влияния факторов процесса напыления: расхода и давления рабочих газов, состава горючей смеси, дистанции напыления, дисперсности распыления, свойств материала проволоки и др. на свойства ЭДН-покрытий.

электродуговое напыление, активирование процесса напыления, износостойкость, коррозионная стойкость, прочность сцепления, плотность, электродуговые покрытия 
Statement of the problem. The use of coatings makes it possible to increase the wear and corrosion resistance of working surfaces of machine parts and mechanisms, in particular ship parts, and so to reduce the costs of alloyed steels and alloys [1].

The coatings application is associated with implementation of a fundamentally new approach, according to which the strength and carrying capacity of a part is provided by its basic material, whereas the resistance to corrosion, wear, and other factors may be increased via using hardening protective coatings. There are many alternative methods for producing coatings, from which it is advisable to choose an optimal, easy to implement, and inexpensive one [2].

Of the variety of methods for hardening coating deposition, the most common technologies used to restore and improve the performance properties of parts are gas-thermal spraying techniques [1,2], among which the cheapest and simplest method is electric arc spraying (EAS), whose current improvement is aimed at modifying and activating the spraying process $[1,2]$.

A significant increase in the properties of EAS coatings is possible through combining arc spraying with ultrasonic [3], electric-spark [3], laser [4, 5-7], electron-beam, and other processing techniques [9].

High wear resistance, hardness, and other surface properties of EAS coatings from iron based alloys can be provided by methods of chemical heat treatment [1,2]. The use of a combination of techniques for EAS and subsequent chemical heat treatment opens up great opportunities in creating composite coatings with special properties. Methods for improving the quality of electric arc coatings via subsequent heat treatment or modification are easily implemented in practice, in particular when part dimensions permit it. Such combined technologies do not require additional expensive equipment and operations, which predetermines a reduction in the cost of hardening processes.

Analysis of recent researches and publications. From the standpoint of these conditions, the use of electric arc spraying (EAS) is promising [3]. In the world practice of hardening, recovery, and anticorrosion protection, EAS has become widespread as the most technologically advanced and productive method (productivity is 3-4 times that for flame spraying) [3]. EAS is widely used in the European countries and displaces the traditional gasflame method [3]. This is due to the simplicity of the equipment, the availability of energy source for metal melting, higher thermal efficiency, which reaches 57\% compared to 13 and $17 \%$ for gas and flame spraying [3]. The quality of EAS coatings are practically the same as that of coatings produced by plasma and detonation methods, and the coating-to-base adhesion strength is greater than in the case of flame spraying. In [3], information is given about the advantages of EAS over surfacing in terms of labor input and consumption of electrode material: duration of surfacing is $1 \mathrm{~h} 10 \mathrm{~min}$ and wire consumption $1.3 \mathrm{~kg}$, while for EAS these parameters are $24 \mathrm{~min}$ and $0.95 \mathrm{~kg}$, respectively.

The successful use of EAS is provided by its advantages such as obtaining coatings with a thickness of 0.1 to $10 \mathrm{~mm}$; the absence of significant thermal effects on the part; the possibility of applying coatings on parts made of various materials; obtaining coatings with desired properties, et al. EAS is characterized by technological flexibility concerning application to various standard sizes of parts, low recovery cost (by 1.4-1.8 times lower than for surfacing). The equipment on which coating is performed is relatively simple and light and can be moved fairly quickly. The part dimensions do not limit the use of EAS [3]. This method is effective and economical in the manufacture and renovation of parts in the conditions of repair enterprises and small workshops with a single production [3]. 
The EAS process consists in heating (to melting) converging wires (electrodes) by an electric arc and spraying the molten metal with compressed air [3]. Two wires move forward in two channels in the spray head, and between their tips an electric arc is excited.

A jet of compressed gas (air), which sprays the molten metal wires and transports the melt in the form of particle flux to the surface being restored (or hardened), flows out of the central channel of the EAS apparatus head. For spray, a wire with a diameter of $0.8 ; 1.0 ; 1.6$, and $2.0 \mathrm{~mm}$ is traditionally used. The use of thermoreacting cored wires is promising [3]. It should be noted that in the course of EAS, the sprayed metal in the form of droplets falls on a substrate and cool to the substrate temperature for a short time, providing the formation of quenched structures in the coating; herein the hardness of the sprayed layer exceeds that of the starting material [3].

The EAS technology includes three main procedures: jet-abrasive processing, deposition of a sublayer from refractory Ni-Cr alloy, and deposition of a main layer of carbon alloyed steel $[9,10]$. The coating obtained is machined with some allowance. The main types of processing sprayed coatings are cutting and grinding. For processing coatings from corrosion-resistant and carbon steels, high-speed and hard-alloy tools may be used. Pretreatment of the base surface is an important factor for providing strong adhesion of the sprayed coating to the part $[9,10]$. The increase in the adhesion strength is associated with an increase in the part area and preparation of a developed surface roughness on before spraying.

The main EAS process parameters are: the composition, diameter, and feed speed of wires to be sprayed; arc power; flow rate of spraying gas; spraying distance; velocity of the spray spot. Traditionally, the distance from the spraying apparatus is $100-200 \mathrm{~mm}[9,10]$.

In addition to the positive qualities of EAS (manufacturability, simplicity, high efficiency, absence of thermal conductors, low cost, versatility, etc.), there are also disadvantages such as increased metal oxidation; the presence of porosity; insufficient adhesion of the coating to the base; cooling of the molten metal particles with spraying compressed air, etc. As a result of the latter, cracks and peels may appear due to the presence of residual internal stresses $[9,10]$. Small feed speeds of the wire lead to its oxidation, and a large amount of heat generated during arc burning leads to a significant burning out of the alloying elements included in the material being sprayed (for example, the carbon content in the coating material decreases by $40-60 \%$, and silicon and manganese by $10-15 \%$ ).

The microstructural analysis made it possible to establish that coatings obtained with the use of wires containing a high percent (from 0.8 to 2.3) of silicon and manganese have the most porous structure due to iron insoluble slags, and, accordingly, the lowest strength properties as compared to coatings from wires with a lower content of deoxidizers. A conclusion follows that for efficient EAS, it is advisable to use wires with as low content of manganese and silicon as possible, which allows deliverance of the coating obtained from delamination and chipping.

Low hardness of coatings, causing carbon burnout during spraying, was always considered to be a limiting factor for the use of EAS. The maximal achievable hardness of coatings from different steels is within 35-50 $\mathrm{HRC}_{\mathrm{E}}$, which markedly reduces their wear resistance. The above mentioned disadvantages of the EAS procedure limit the efficiency and narrow the area of its application to increase the service life of parts. Despite the large number of innovations concerning EAS, researches on the improvement of this method and required equipment are actively being carried out and has become aimed at activating the spray process using various techniques, methods, and devices $[3,10]$.

Preheating of the substrate was established to lead to decreasing the rates of crystallization, cooling of falling particles, and developing their chemical interaction with the substrate. As a consequence, adhesion strength increases. However, in the case of heating 
above $500 \mathrm{~K}$, the rate of oxide formation increases and adhesion strength decreases. Moreover, preheating to $500 \mathrm{~K}$ is impossible when thin-walled parts are coated because of unavoidable thermal deformation, and this operation is undesirable in restoring parts that operate under alternating or cyclic loads (as fatigue cracks grow under heating).

The use of activation techniques which intensify heat exchange processes in the "jetparticle" system and increase the dynamic parameters of particles, and allows reducing the wire particle size or of those that allow modifying (strengthening) the sprayed layer seems to be most expedient means.

On the basis of studying the problem of hardening and restoring parts of the using EAS coatings, the aim of the work was set up to increase the wear resistance, corrosion resistance, and service life of parts via combining EAS coatings characterized by high density, adhesion strength, and microhardness due to the activation of the spray process

Statement of the objective. The aim of the work was shows the possibility, through the selection of design parameters and characteristics of equipment for EAS, to control the properties of coated surfaces in order to increase the service life of restored parts. The right choice of equipment for EAS allows one to increase the speed and temperature of the jet of spraying gas and particles, decrease the size of droplets, increase the density and reduce the oxidation of coatings. to develop a new combined method of surface engineering for the formation of hardening protective coatings on the basis of combination of EAS.

The main material. For coating deposition, an apparatus for activated arc spraying ADN-10 was used. Coating materials were $0.8-2.8 \mathrm{~mm}$ diameter wire from steel of the martensitic (40Kh13, 95Kh18), ferritic (Sv-08G2S), and austenitic (Kh18N10T, $12 \mathrm{Kh} 18 \mathrm{~N} 10 \mathrm{~T})$ grades. A feature of martensitic and austenitic steels of is the ability to phase transformations and structural changes during deposition and treatment of coatings. This allows improvement of physic mechanical and performance properties of hardened surfaces and an increase in their wear and corrosion resistances. The PIN process lasted $2 \mathrm{~h}$ in the temperature range $600-800 \mathrm{~K}$.

Microstructure was examined on etched and unetched thin sections using a light microscope «MeF-3» (Firm "Reichert", Austria) with magnifications $\times 100, \times 200$, and $\times 500$. The microhardness was measured on a Micromet II microhardness meter with a load of $100 \mathrm{~g}$ from the coating surface edge to the base through the transition zone. A quantitative stereological analysis of coating porosity was carried out on a certified automatic image analyzer "Mini-Magiscan" (Firm "Joyce Loebl", England) using the program "Genias 26". The main stages of the image analysis were: image calibration, image fixation, segmentation, and porosity. The study was performed on a CamScan scanning electron microscope (Oxford Instruments, England) with an X-ray energy dispersive analyzer. The morphology (topography) of the coating surface was examined in the regime of reflected electrons at an accelerating voltage of $10-20 \mathrm{kV}$.

The quality of EAS coatings used for renovation and hardening of the working surfaces of parts markedly depend on the technical characteristics of the equipment used.

Currently, there is in operation a wide range of power sources and devices for spraying produced by various companies [1-7]. However, a comparative analysis of the influence of the main technical characteristics of spray units and power sources on the physicomechanical properties of the coatings obtained has not been carried out; and no science-based recommendations on the use of EAS equipment have been made. The above reasons make it difficult to choose the right equipment for EAS that could provide high performance and quality of the recovered parts. This paper presents the characteristics of the most used units and analysis of them in order to ensure their correct choice. 
The characteristics of the power source and the design of an apparatus for an electric arc determine such EAS factors as the welding current; the type, pressure, and flow rate of the spraying gas; the diameter and shape of the nozzle, and the scheme of a blowing system.

To create EAS coatings, units with various blowing systems and nozzle geometry are used $[8,9]$. Currently, there are several schemes for the formation of the metal-air flow for EAS, namely diaphragm, central-nozzle, differential, and closed ones. In particular, the most widespread diaphragm scheme is used in the manufacture of EAS units at the Barnaul plant (Russia) and firms "Metco" and "Mogul" (the United States). For this scheme, formation of a fairly wide metal-air flow is characteristic. The use of it is effective for obtaining anticorrosion coatings. The central nozzle scheme is used in the electric arc apparatus EM-17 (Barnaul), where a narrow metal-air flow is created, which is particularly efficient for coating of bodies of revolution, for example shafts, including crankshafts [8,9].

At the Physical-Mechanical Institute (PMI) of NAS of Ukraine (Lviv), through improving the design of EAS equipment and increasing the protective-energy level of the spray arc flame, the problem of increasing the physicomechanical properties of coatings was solved by weakening the dispersed metal oxidation in the spray flame and increasing the velocity of particles $[8,9]$. In order to improve the quality of coatings, an electric arc apparatus with a spray head was used $[8,9]$, which was based on a closed scheme for the formation of metal-air flow (Fig. 1). Such a scheme is used in the units manufactured by the GMP "Gasothermic" at PMI of NAS of Ukraine.

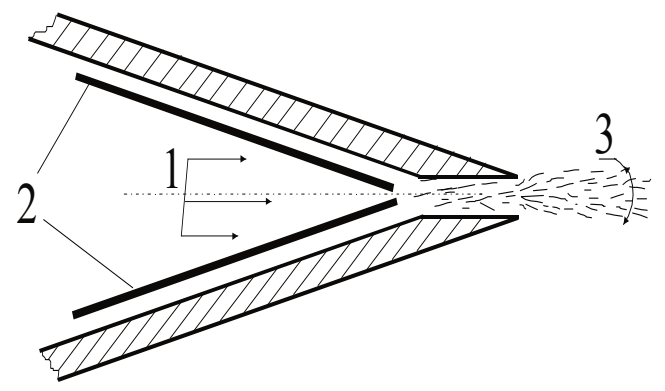

Figure 1 - A closed scheme for formation of metal-air flow during EAS: (1) air flow; (2) cored wire;

(3) annular divergence of the metal-air flow (10-15)

Source: compiled by the author using data from [12]

The advantages of EM-14 units with a closed scheme and a differential nozzle over an open scheme and a central nozzle are considered in [8-11]. The closed scheme of metal-air flow formation allows the manufacture of extremely fine fractions of sprayed particles (below $50 \mu \mathrm{m})$ thanks to their high flight velocity $(50-130 \mathrm{~m} / \mathrm{s})$ from the burning arc zone to the surface being restored (Fig. 2). Such a spray scheme (Fig. 2) should be used when the need arises in fine-particle $(50-200 \mu \mathrm{m})$ coatings via spraying wires that include refractory components.

If the metal-air flow scheme is closed, the arc burns in a channel bounded with the spray head of the EAS apparatus. This scheme realizes its advantages when the arc cross section size becomes commensurate with the cross section of the cylindrical channel where it burns. The closed metal-air flow scheme allows two deposition modes: continuous and pulsed. Upon reducing the diameter of the nozzle cylindrical part, the pressure in the nozzle may become equal to that in the arc gap. With this, cold air may actively penetrate into the arc burning zone and so help decrease its length. When the arc length decreases so much that the melt can close the arc gap, a pulsed mode is realized. The pressure in the arc markedly depends on the nozzle diameter and arc power. 
It was established experimentally that the larger the nozzle diameter, the greater the arc power should be in order to realize the pulsed mode of the electric arc apparatus operation. When the pulverization apparatus is in the pulsed mode, the wire tips become parallel. The liquid phase closes the tips, and the reycotron effect is realized, which is manifested in the fact that an electrodynamic force acts parallel to the surfaces of wires, which melt in the gaps between the two parallel wires-electrodes. The melt is ejected from the gap by electrodynamic forces, and after a pause the cycle repeats. The frequency of emissions depends on the wire feed speed. Portions of the liquid metal receive an additional impulse owing to the reycotron effect, which increases the velocity of particles and contributes to the melt dispersion.

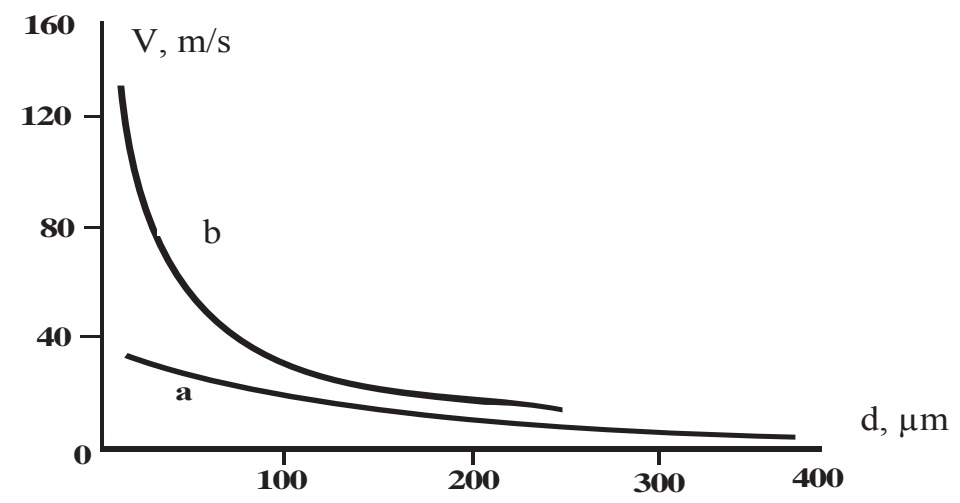

Figure 2 - Dependence of the velocity of metal particles on their size for different modes of metal-air flow formation: (a) central nozzle scheme; (b) closed scheme

Source: compiled by the author

The use of the closed scheme for the formation of metal-air flow during EAS [8-11] allows production of coatings with a density of over $90 \%$ and adhesion strength to $180 \mathrm{MPa}$. The maximum size of sprayed particles does not exceed $50 \mu \mathrm{m}$. Thus, the EM-14 spraying system (Fig. 3), which provides arc burning in a channel bounded with the nozzle walls or in the formed flow of pressing air, makes it possible to produce droplets with a high flight velocity, which improves the properties of the surfaces being restored.

In the apparatus EDM-6GD designed by the Mariupil State University and the company TOPAZ, spraying is performed with gas-dynamic dispersion of metal and using an external chamberless combustion scheme. Here the energy source (electric arc and compressed air) is replaced by an electric arc and a fast jet of the products of liquid hydrocarbon fuel combustion [8-11]. This design allows reduction in the oxidation potential of the medium compared to air by twice and improvement in the properties of surfaces restored. The adhesion strength of coatings increases by $56 \%$ and hardness by $18 \%$, while the porosity of coatings decreases by 2.6 times. At the same time, the cost of the EAS process decreases thanks to the replacement of cored wires with 2-3 times cheaper standard soliddrawn ones. 


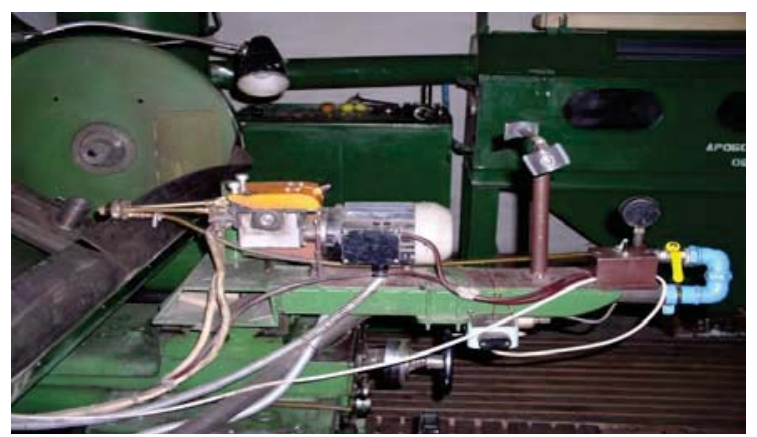

Figure 3 - Apparatus EM-14 for EAS

Source: compiled by the author using data from [12]

The units for EAS produced by NPOOO "MAD" (Minsk) combine the advantages of electric arc and fast spraying [8-11] (Fig. 4). The main distinguishing feature of the EAS unit is the presence of an efficient small-sized chamber for propane/air mixture combustion. A fast jet of the combustion products leaves it with a speed of $1500 \mathrm{~m} / \mathrm{s}$ at the outlet. The unit operates on the basis of melting wires by an electric arc and spraying molten wire droplets with the fast jet of combustion products. It requires supply of compressed air with pressure from 0.6 to $0.8 \mathrm{MPa}$ and propane with pressure from 0.3 to $0.45 \mathrm{MPa}$ as well as a source of welding current with a "hard" voltage-current characteristic (of the "VDU-506" type). By varying the consumption of propane and air, it is possible to create a neutral or reducing atmosphere in the melting zone of the electrode wire and thereby to weaken metal oxidation and burnout of alloying elements [8-11]. Moreover, the design features of such units make it possible to increase the velocity of sprayed material particles and the coefficient of material utilization to 0.85 ; herein the jet angle does not exceed $10^{\circ}$.

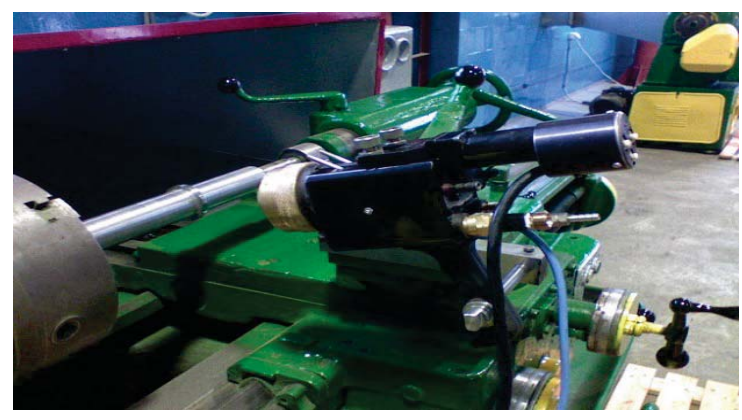

Figure 4 - Unit for EAS with a propane-air combustion chamber Source: compiled by the author using data from [3]

The EAS-10 unit has an electric drive which provides the required speed of wire electrode feed. It is powered from a three-phase network of $220 \mathrm{~V}$, frequency $50 \mathrm{~Hz}$. In the case of using an alternating current, the electric arc burning proceeds with periodic interruptions that occur as a result of the voltage drop. The power supply for the electric arc apparatus with a direct current forms the necessary conditions for obtaining coatings with a uniform thickness. Analysis of the research results made it possible to recommend the EM-14 apparatus (Fig. 3) and the EAS-10 unit (Fig. 4) for deposition of EAS coatings. The proper management of the design parameters of equipment for EAS provides the creation of coatings with high performance characteristics, which is very important for increasing the service life of parts. 
Thus, the work shows the possibility, through the selection of design parameters and characteristics of equipment for EAS, to control the properties of coated surfaces in order to increase the service life of restored parts. The right choice of equipment for EAS allows one to increase the speed and temperature of the jet of spraying gas and particles, decrease the size of droplets, increase the density and reduce the oxidation of coatings. Additionally, it has made it possible to use standard solid-drawn wires from martensitic steels $40 \mathrm{Kh} 13$ and $95 \mathrm{Kh} 18$ and austenitic steels Kh18N10T and 12Kh18N10T instead of more expensive cored wire FMI.

A distinct feature of the martensitic and austenitic steels is the ability for phase transformations and structural changes during deposition and processing of coatings, which results in improving the physicomechanical and operational properties of hardened surfaces. The process of restoration of SMM surfaces via EAS coating is divided into three main stages: surface preparation, coating, and subsequent treatment of the surface coated.

Conclusions. The present work recommends to increase the wear resistance, corrosion resistance, and service life of parts via hardening and renovating them using EAS coatings characterized by high density, adhesion strength, and microhardness due to activation of the spraying process. It has been shown that by properly choosing design parameters and characteristics of equipment for EAS, it is possible to control the properties of restored surfaces in order to increase the service life of parts. The right choice of equipment for spraying will allow one to increase the speed and temperature of the jet of spraying gas and molten particles, decrease the droplet diameter, increase the density, and reduce the oxidation of coatings.

The research has revealed the influence of the spraying process factors such as the flow rate and pressure of working gases, composition of combustible mixture, spraying distance, dispersion of spray, properties of the wire material, etc. on the properties of EAS coatings. Furthermore, the effects of the spraying distance, the size of sprayed particles, and the properties of the wire material on the porosity and coating-to-substrate adhesion was evaluated. Moreover, the phase composition and microhardness of coatings obtained by spraying wires from austenitic and martensitic steel were investigated. The presence of an abnormally large amount of residual austenite (to $50 \mathrm{vol} \%$ ) in coatings from martensitic steel was established.

Studies of the resistance to fatigue failure showed that coatings deposited by EAS of wires provide a slight decrease in the fatigue strength limit to 10-13\% (for comparison, coatings obtained by vibro-arc surfacing reduce the fatigue limit by $35-40 \%$ ).

\section{References}

1. Ageev M.S., Volkov Ju.V., Chigraj S.L. Zashhitnye i uprochnjajushhie pokrytija v sudostroenii i sudoremonte. Nauk. Visnik HDMA . Herson: HDMA. 2015. № 2 (13). P.110-124.

2. Ageev M.S., Volkov Ju.V., Chigraj S.L. Cvarka i rodstvennye processy v sudostroenii . Sbornik nauchnyh trudov «Vodnyj transpor». Kiev, KGAVT. 2015. Vol. №2(24). S. 15-26.

3. Boronenkov V. N., Korobov Ju. S. Osnovy dugovoj metallizacii. Fiziko-himicheskie zakonomernosti. UrGU; Ekaterinburg: Univ. izd-vo. 2012. 267 p.

4. M.S. Ageev, B.A. Ljashenko, Primenenie gibridnyh tehnologij dlja renovacii i povyshenija resursa sudovyh mashin i mehanizmov. Vestnik Brestskogo gosudarstvennogo tehnicheskogo universiteta. Nauchno-teoreticheskij zhurnal Mashinostroenie. 2015. 4(94). P. 18-22.

5. $\quad$ Ageev M.S. Kozhevnikova E.E., Lopata V.N. Vosstanovlenie valov sudovyh nasosov kombinirovannym sposobom nanesenija zashhitnyh pokrytij. Naukovij visnik HDMA . Herson. 2015, № 2 (13). P. 4-16.

6. Kozhevnikova E.E., Ageev M.S., Chigraj S.L. Povyshenie resursa sudovyh nasosov na osnove kombinirovannoj tehnologii vosstanovlenija. Sbornik nauchnyh trudov «Vodnyj transpor». Kiev, KGAVT. 2015. Vol. №2(24). P. 57-70.

7. Vilage B., Ruppreht K., Pohmurskaja A. Osobennosti gazotermicheskogo napylenija pokrytij poroshkovymi provolokami. Avtomaticheskaja svarka. 2011. № 10. P. 26-30. 
8. Belocerkovskij M.A., Konstantinov V.M., Tkachenko G.A. Uprochnenie himiko-termicheskoj obrabotkoj pokrytij, poluchennyh vysokoskorostnym raspyleniem stal'nyh provolok. Inzhenerija poverhnosti, Novye poroshkovye kompozicionnye materialy. Svarka: sb. dokl. Mezhd. Simpoziuma, Minsk, 25-27 marta 2009 g./ Institut poroshkovoj metallurgii GNPO PM NAN Belarusi; redkol.: P.A. Vitjaz' [i dr]. Minsk, 2009. S. $178-184$.

10. B.A. Ljashenko, M.A. Belocerkovskij V.N. Lopata, Ju.V. Brusilo, Korbut E.V. Gazotermicheskoe napylenie i ionnoe azotirovanie - perspektivnoe sochetanie. Inzhen. poverhn. i renovacija izdelij: Mater. 14-j mezhdun. nauchn.-tehn. konf., 2-6 ijunja 2014, Svaljava - Kiev: ATM Ukrainy, S.79-80.

11. A.S. Prjadko, A.V. Dudan, Ju.V. Brusilo, T.V. Vorona, Ju.V. Volkov Vybor oborudovanija dlja uprochnenija i vosstanovlenija detalej avtomobil'nogo transporta jelektrodugovym napyleniem. Vestnik Polockogo gosudarstvennogo universiteta. Promyshlennost'. Prikladnye nauki. Polock. 2014. № 3, S. 121-126.

12. Ju.V. Brusilo Vybor oborudovanija dlja uprochnenija i vosstanovlenija detalej porshnevyh dvigatelej jelektrodugovym napyleniem. Nauchno-tehnicheskij zhurnal «Aviacionno-kosmicheskaja tehnika $i$ tehnologija». Har'kov. 2010. №4 (71). S. 38-42.

13. Elektrodugovi vidnovni ta zahysni pokryttja / V.I. Pohmurs'kyj, M.M. Student, V.M. Dovgunyk, G.V. Pohmurs'ka, I. J. Sydorak. L'viv: Fiz.-meh. in-t im. G.V. Karpenka NAN Ukrai'ny, 2005. 190 s.

М.С. Агєєв, доц., канд. техн. наук

Херсонська державна морська академія, м. Херсон, Украӥна

С.А. Довжук, зав. лаб.

Центральноукраїнський національний технічний університет, м Кропивницький, Украӥна

В.Я. Ніколайчук, асист., Т.С. Хрипко, асист.

Вінницький національний аграрний університет, м Вінниця, Украйна

Вплив конструктивних параметрів обладнання для електродугового напилення на фактори процесу напилення та властивості покриттів

Мета досліджень в пропонує мій статті полягає в визначенні впливу конструктивних параметрів апаратів для електродугового напилення на процес нанесення покриття та його властивості.

В роботі запропоновано підвищувати зносостійкість, міцність зчеплення, щільність, корозійну стійкість, мікротвердість і термін служби деталей машин і механізмів при їх зміцненні та реновації електродуговими покриття за рахунок активації процесу напилення. Активування процесу електродугового напилення здійснювали шляхом розробки спеціальної камери згорання в електродуговому апараті.

При проведенні досліджень розглянута можливість за рахунок вибору конструктивних параметрів і характеристик обладнання для ЕДН управляти властивостями відновлених поверхонь 3 метою підвищення ресурсу деталей машин. Правильний вибір конструкції обладнання для напилення дозволив збільшити швидкість і температуру струменя транспортуємих газу і частинок, зменшити діаметр крапель, підвищити щільність і знизити окислюваність покриттів. В роботі виконані дослідження впливу чинників процесу напилення: витрати і тиску робочих газів, складу горючої суміші, дистанції напилювання, дисперсності розпилення, властивостей матеріалу дроту і ін. на властивості електродугових покриттів.

Виконані дослідження показали, що за рахунок вибору конструктивних параметрів та характеристик обладнання для електродугового напилення можливо керувати процесом ЕДН і отримати необхідні властивості покриттів та поверхонь, що відновлюються з метою підвищення ресурсу деталей машин.

електродугове напилення, активування процесу напилення, зносостійкість, корозійна стійкість, міцність зчеплення, щільність, електродугові покриття 